\title{
PERAN GURU PENDIDIKAN AGAMA ISLAM DALAM MEMBANGUN SEMANGAT KEBERAGAMAN BERAGAMA DI SMPN 13 KOTA KUPANG
}

\author{
Zikry Septoyadi ${ }^{1}$, Vita Lastriana candrawati ${ }^{2}$, Adi Ahmad Rezal ${ }^{3}$ Junanah $^{4}$ \\ Magister Ilmu Agama Islam Universitas Islam Indonesia ${ }^{1,2,4}$ \\ Pendidikan Agama Islam Universitas Islam Indonesia ${ }^{3}$ \\ email:20913050@ @students.uii.ac.id,20913093@students.uii.ac.id, \\ 16422036@students.uii.ac.id, Junanah@uii.ac.id
}

\begin{abstract}
This research was started when the writer felt uneasy about cases concerning religious issues that have recently occurred in Indonesia. Either on purpose or not. Now there are a lot of certain people who become elements of a problem regarding religion in Indonesia, as well as when certain groups have liberal beliefs where they lack socialization in society. This study aims to describe the perspectives of an Islamic Education teacher and also the principle of religious diversity in schools. The type of research used is descriptive qualitative. Where the researcher looks for several sources and then puts them together and in the sense that the research is meant to gather information about the status of an existing symptom. The data collection technique was done by observing, interviewing, and documenting. As well as research subjects consisting of PAI teachers, school principals, Muslim students, and Christian students. This research was conducted directly at SMPN 13 Kupang City. From the results of the research carried out, it can be concluded that the task of a teacher is not just teaching but also the teacher can provide examples and motivation that is useful for students, besides that a teacher also has an important role in the community and also religious values. We must, but we will protect it so that in the future there will be no more cases regarding religion in Indonesia.
\end{abstract}

Keywords: Religious Diversity, The Role of Teachers, Learning

Di Indonesia dikenal memiliki keberagaman yang merupakan salah satu konteks kehidupan masyarakat yang telah disadari sejak awal berdirinya negara kita, sehingga semboyan "Bhinneka Tunggal Ika" dijadikan sebagai salah satu falsafah bangsa Indonesia. Perbedaan dan keberagaman merupakan aset dan sumber daya yang perlu dikembangkan oleh bangsa kita. Indonesia adalah salah satu negara multikultural yang memiliki keragaman budaya, ras, suku, agama, dan golongan yang kesemuanya merupakan kekayaan tak ternilai yang dimiliki oleh bangsa ini. Namun faktanya yang terjadi belakangan ini sering terjadi konflik yang melibatkan suku, sosial, sparatisme, dan yang paling utama yaitu agama, dan masih banyak lagi kasus-kasus yang terjadi di Indonesia, contohnya yang terjadi di kota Surabaya ketika umat Nasrani sedang melakukan ibadah kemudian terjadi ledakan di kawasan sekitar gereja tersebut, itu merupakan salah satu contoh konflik agama yang terjadi di Indonesia. 
Provinsi Nusa Tenggara Timur sendiri sudah sejak lama masyarakatnya hidup dalam perdamaian walaupun di sana tinggal beragam masyarakat yang memiliki latar belakang agama yang berbeda-beda, peneliti sendiri sejak kecil sudah memiliki teman bahkan keluarga yang berbeda agama. Mayoritas pemeluk agama di provinsi NTT yang pertama adalah Katolik dengan angka 55,39\%,kedua Kristen Protestan dengan angka 34,32\%, ketiga Islam dengan angka 9,05\%, keempat Merapu dengan angka 1,05\%, kelima Hindu dengan angka 0,18\%, dan yang keenam Budha $0,01 \%$. Itu adalah jumlah peresntase pemeluk agama di NTT.( Badan Pusat Statistik Provinsi NTT : 2019)

Sedangkan di ibu kota provinsi NTT Kota Kupang tempat peneliti tinggal hidup juga berbagai macam orang yang memiliki keberagaman yang berbedabeda, kota Kupang adalah kota paling besar yang terdapat di Provinsi NTT sehingga orang-orang banyak yang berdatangan ke sana, yang datang ke sana bukan hanya orang-orang dari NTT melainkan banyak juga dari luar NTT seperti dari Jawa, Bugis, Padang, Kalimantan, China dan masih banyak lagi. Di kota Kupang sendiri kasus yang membawa agama terakhir terjadi di penghujung tahun 1998, setelah itu sering terdengar isu tentang kerusuhan antara agama namun tidak pernah terjadi kerusuhan secara nyata. Agama yang dianut masyarakat di kota Kupang ada 5 agama yaitu yang pertama Kristen Protestan dengan populasi 71,32 $\%$, kedua Katolik dengan populasi 17,05 \%, ketiga Islam dengan populasi 10,09 $\%$, keempat Hindu dengan populasi 1,53\%, kelima Budha dengan populasi 0,01 $\%$, dan lain-lain dengan populasi 0,52 \%. (Badan Pusat Statistik Provinsi NTT : 2019)

Dari presentase tersebut dapat diilihat bahwasanya agama mayoritas adalah Kristen Protestan dan sisanya masuk ke dalam golongan minoritas, namun selama penulis tinggal di sana tidak pernah ada kerusuhan yang terjadi, terkadang terdengar akan terjadinya kerusuhan yang melibatkan agama namun itu hanya sebagai kabar angin semata. Masyarakat di sana hidup sangat berdampingan bahkan ketika bulan ramadhan tiba para umat Nasrani juga ikut menyambutnya dengan cara ikut dalam pawai takbiran, menjaga lalulintas sekitar masjid ketika shalat tarawih dan shalat ied, begitupula umat Islam di sana ketika natal tiba maka

Zkry Septoyadi, Vta Lastriana candrawati, Adi Ahmad Rezal
(Peran Guru Pendidikan Agamra IslamDalamMenbangun..)
Da.10.2397//ff.v5i22794


setiap dewan-dewan masjid yang ada di kota Kupang meminta kepada para remaja masjid untuk menjaga lalu lintas di sekitar gereja tempat umat Kristen dan Katolik beribadah.

Namun kasus yang sering terjadi belakangan ini di Indonesia adalah kasus yang melibatkan isu agama, hal ini yang mebuat peneliti takutkan akan berdampak terhadap masyarakat di Kota Kupang, karena watak warga Kota Kupang yang mudah terprovokasi dengan isu mengenai suku, ras, dan agama dan juga watak orang-orangnya yang keras, maka jika sampai ada kerusuhan yang terjadi di sana maka pastinya akan memakan banyak korban. Contohnya di tahun 2011 terjadi kasus kerusuhan antara warga kota Kupang dengan orang-orang pendatang dari Bugis, kerusuhan tersebut dikarenakan ada isu dari luar yang mengatakan bahwa orang bugis meludahi salah satu gereja di kota Kupang.

Dari uraian tersebut peneliti menyimpulkan bahwasanya jika sampai ada terjadi kerusuhan yang melibatkan agama maka agama minoritas disanalah yang akan banyak berjatuhan korban khususnya di kota Kupang, namun syukur Alhamdulillah semenjak kejadian di penghujuang tahun 1998 tidak pernah terjadi lagi kasus yang melibatkan agama di kota Kupang, bahkan sampai sekarang kota Kupang terpilih menjadi kota paling tinggi toleransinya di Indonesia menempati urutan ke 7 setelah kota Singkawang, Salatiga, Pematang Siantar, Manado, Ambon, dan Bekasi. (Hailil, 2018 : 49) Untuk menjaga hal itu tetap bertahan pemerintah dan masyarakat harus terus berjuang dalam menjaga sikap toleransi dan saling menghargai antara umat beragama.

Dalam membangun kesadaran dalam keberagaman itu tidaklah mudah, instrumen paling memungkinkan untuk membumikan kesadaran dalam keberagaman agama salah satunya adalah melalalui pendidikan. Dengan pendidikan, guru menemukan media untuk mengenalkan keberagaman agama yang ada di Indonesia secara lebih mendasar sebagai upaya untuk mencegah adanya konflik horisontal dan disintegrasi bangsa. Disinilah pentingnya studi mengenai peran guru dalam membangun kesadaran adanya keberagaman dan kebhinekaan melalui pendidikan memiliki relevansi yang cukup signifikan dalam memotret realitas kebangsaan.

Zkry Septoyadi, Vita Lastriana candrawati, Adi Ahmad Rezal
(Peran Quru Pendidikan Agama Islam DalamMembangun..)
Da.10.2397/ff.v5i22794


Pendidikan Agama Islam sebagai bagian integral dari pendidikan nasional maka penerapannya tidak terlepas dari pencapaian tujuan pendidikan nasional disamping pencapaian tujuan pendidikan agama Islam itu sendiri. Konsep pendidikan agama Islam dalam membentuk kepribadian peserta didik merujuk pada kemampuan dasar yang sudah dimiliki oleh peserta didik itu sendiri, yang diarahkan untuk meningkatkan keimanan, pemahaman, penghayatan dan pengamalan peserta didik tentang agama Islam, sehingga sikap keagamaam peserta didik senantiasa sesuai dengan ajaran-ajaran Islam. Kegiatan proses pembelajaran di sekolah merupakan inti dari seluruh rangkaian kegiatan yang berlangsung di sekolah. Kegiatan proses belajar ini adalah kegiatan di dalamnya terjadi proses interaksi antara guru dan peserta didik. (Syaiful bahri Djamarah, 2014 : 112) Guru dan peserta didik adalah unsur yang tidak dapat dipisahkan khususnya dalam proses pembelajaran.

Keberadaan guru dalam proses pembelajaran memegang peranan penting. Peranan guru dalam proses pembelajaran tidak dapat digantikan dengan alat elektronik yang canggih seperti radio, TV, computer dan sebagainya. Alasan peneliti memilih untuk melakukan penelitian di SMPN 13 Kota Kupang karena menurut peneliti ada hal unik yang terdapat di sekolah tersebut, keberadaan agama Islam di sekolah tersebut tentu menjadi minoritas karena seperti yang telah dibahas sebelumnya agama Kristen dan agama Katolik menjadi agama mayoritas di Kota Kupang sehingga apakah ada perbedaan yang signifikan ketika menjadi seorang guru Pendidikan Agama Islam dalam mengajarkan ilmu agama dan juga mengajarkan keberagaman sebagai minoritas di sekolah tersebut.

Penelitian ini memiliki beberapa tujuan yaitu: Mengetahui upaya dari guru Pendidikan Agama Islam dalam membangun semangat keberagaman beragama yang ada di SMPN 13 Kota Kupang. Mengetahui implementasi pembelajaran agama Islam dalam konteks keberagaman agama peserta didik di SMPN 13 Kota Kupang. Mengetahui bentuk peran guru Pendidikan Agama Islam SMPN 13 Kota Kupang baik di dalam kelas maupun di luar kelas. 
Penelitian ini menggunakan pendekatan kualitatif dan penelitian yang bersifat deskriptif analisis, yaitu penelitian yang dimaksudkan untuk mengumpulkan informasi mengenai status suatu gejala yang ada, yaitu keadaan gejala menurut apa adanya seperti yang terjadi berdasarkan pra surve yang penulis lakukan di SMPN 13 kota Kupang.. Dalam penelitian ini subjeknya yaitu, guru pendidikan agama islam, kepala sekolah SMPN 13 kota Kupang dan peserta didik SMPN 13 kota Kupang. Alat pengumpulan data yang digunakan adalah observasi, wawancara dan dokumentasi. Pada penelitian kualitatif, data yang telah dikumpulkan dan didapatkan akan dianalisis dengan pendekatan kualitatif model interaktif yang terdiri dari tiga tahapan yaitu reduksi data, penyajian data, dan penarikan kesimpulan atau verifikasi.

\section{PEMBAHASAN}

\section{Upaya guru Pendidikan Agama Islam dalam membangun Semangat keberagaman beragama di SMPN 13 kota Kupang}

Sesuai dengan observasi dan penelitian yang dilaksanakan pada tanggal 27, 28, 29 dan 30 Juli 2020. Penulis berhasil mendapatkan data yang penulis inginkan terkait dengan perspektif guru PAI terhadap keberagaman agama di SMPN 13 Kota Kupang, pada saat melakukan observasi di sekolah peneliti tidak dapat mengikuti kelas secara langsung dikarenakan adanya pandemi covid 19 sehingga penulis mengikuti kelas secara online yang diikuti oleh guru PAI di SMPN 13 Kota Kupang bapak Deddy Sanjaya dan sebagian siswa kelas 7. Keberagaman agama di SMPN 13 Kota Kupang selama ini berjalan dengan baik dan harmonis baik itu di kalangan para siswa ataupun para guru-gurunya. Contohnya ketika ada hari raya dalam agama Kristen seperti hari raya Natal maka mereka juga mengundang para guru dan sebagian siswa yang beragama Islam, ketika ada hari raya Islam seperti Maulid Nabi juga turut mengundang guru dan sebagian siswa yang beragama Kristen dan juga Katolik dan juga ketika ada doa bersama mereka melaksanannya dalam satu ruangan dan berdoa bersama-sama menurut keyakinan masing-masing . Berikut pemaparan wawancara bersama dengan narasumber pertama bapak Deddy Sanjaya: 
"Keberagaman itu adalah fitrah dari seorang manusia, Allah menciptakan kita itu berbeda-beda ada yang putih, ada yang hitam, ada yang tinggi, ada yang pendek, ada yang pintar ada yang bodoh, begitu juga mengenai iman ada orang-orang yang beriman ada juga orang-orang yang tidak beriman, ada orang-orang yang percaya sama Allah ada juga yang tidak itu semua pada dasarnya memang sudah diatur sama yang diatas tinggal saja tugas kita bagaimana caranya kita manusia yang beda-beda ini bisa hidup berdampingan satu sama lain tanpa perlu adanya apa e rasa iri atau rasa saling menyalahkan karna perbedaan itu tadi, nah maka disini kita harus sama-sama menjaga agar terhindar dari itu”

Melalui hasil wawancara diatas bapak Deddy Sanjaya mengungkapkan bahwasanya keberagaman merupakan fitrah yang diberikan oleh Allah kepada umat manusia, manusia dilahirkan dalam bentuk dan keadaan yang berbeda-beda ada yang kaya, ada yang miskin, ada yang hitam kulitnya, ada yang putih kulitnya, bahkan Allah juga menciptakan manusia dalam keadaan yang beriman dan tidak beriman kepadanya, hal ini sebagaimana seperti teori yang penulis gunakan yaitu menurut Tafsir Al-Muyassar sekiranya Tuhanmu menghendaki agar semua orang yang ada di muka bumi ini beriman, niscaya mereka semua pasti beriman. Akan tetapi Allah tidak menghendaki hal itu karena hukmah tertentu. Dia menyesatkan orang yang dikehendakinya berdasarkan keadilannya. (Aidh bin Abdullah Qarni, 2017: 107)

Dari narasumber pertama selaku guru PAI di SMPN 13 Kota Kupang. Dari hasil wawancara tersebut diketahui bahwasanya keberagaman agama menurut perspektif bapak Deddy Sanjaya di SMPN 13 Kota Kupang sudah berjalan dengan baik dan juga harmonis, tidak pernah ada masalah yang terjadi. Ada hal yang menarik dari wawancara diatas pak Deddy Sanjaya mengakatakan bahwasanya di SMPN 13 Kota Kupang sering diadakan acara hari raya dalam agama seperti:

a. Maulid Nabi bersama

b. Isra Miraj bersama

c. Halal bi Halal

d. Natal bersama 


\section{e. Paskah bersama}

Dari kegiatan-kegiatan diatas ada hal yang menarik, karena ketika kegiatan perayaan hari raya tersebut para siswa dan guru turut diundang dalam acaranya baik itu Maulid Nabi, Isra Miraj, Halal bi Halal, Natal bersama, dan Paskah bersama. Dalam kegiatan-kegiatan ini mereka selalu berkumpul bersama tidak harus hanya yang seiman yang boleh hadir dalam acara perayaan tersebut namun semuanya turut ikut serta dalam acara tersebut, dengan adanya acara-acara ini dengan sendiri akan tertanam dalam diri para siswa tentang nilai-nilai keberagaman dan toleransi terhadap satu sama lain, dan juga telah menggambarkan bahwasanya para guru dan siswa di SMPN 13 Kota Kupang telah memberikan gambaran suatu masyarakat yang majemuk yang terdiri dari ras, agama, bahasa, dan budaya yang berbeda yaitu masyarakat pural, masyarakat heterogen, dan masyarakat multikultural.

Menghargai keberagaman dan memiliki semangat toleransi bagi masyarakat Kota Kupang merupakan suatu kewajiban karena keadaan masyarakat yang beragam yang menghuni Kota Kupang, begitu juga semangat toleransi tersebut harus ditingkatkan di lingkungan-lingkungan sekolah agar nantinya para siswa tidak menjadi orang yang memiliki sikap intoleran di masyarakat.

Narasumber pertama memiliki pendapat mengenai masalah yang marak terjadi belakangan ini, yang mana melibatkan agama dimana mereka tidak setuju akan hal itu dan mereka sebagai guru juga mengupayakan agar hal-hal serupa tidak terjadi kepada siswa di SMPN 13 Kota Kupang

Negara Indonesia telah menjamin hak-hak untuk beragama kepada seluruh rakyatmya sebagaimana yang tertera dalam Undang-Undang Dasar 1945 pasal 29 ayat (2) yang berbunyi "Negara menjamin kemerdekaan tiap-tiap penduduk untuk memeluk agamanya masing-masing dan untuk beribadat menurut agamanya dan kepercayaan itu”. (Undang-Undang Dasar 1945, 2003:2) Dari gagasan UUD tersebut sudah sangat jelas dan tegas bahwa negara menjamin setiap warga negeranya untuk beragama dan beribadah sesuai dengan ajarannya masing-masing tanpa ada gangguan atau paksaan dari pihak manapun. Dari wawancara dua narasumber 
diatas dapat kita pahami bahwasanya sangat penting bagi kita untuk menjaga keutuhan negara demi terbentuknya masyarakat yang plural, heterogen, dan multikultural.

Dari hasil observasi dan wawancara yang penulis lakukan maka ini sesuai dengan teori yang penulis gunakan yaitu menurut Tafsir Min Fathil Qadir dimana Allah tidak akan melarang hambanya untuk berbuat baik kepada orang-orang yang tidak memerangi agama hambanya dan tidak mengusir hambanya dari kampung halamannya. Umatnya diperbolehkan untuk bersilaturahmi dengan mereka atau saling mengasihi sesama tetangga. Allah juga tidak melarang umatnya untuk berperilaku adil. Allah mencintai orang-orang yang berlaku adil dan membersihkan jiwa mereka. Dan juga Allah melarang setiap mu'min membawa kemarahan mereka terhadap orang-orang kafir menjadikannya tidak berbuat adil kepada mereka. ( Imam Asy-Syaukani, 2012:477)

Hal ini dipertegas oleh Masykuri Abdillah dalam "Toleransi Beragama dalam Masyarakat Demokrasi dan Multikultural". Tulisan ini menakan pada perlunya nilai-nilai toleransi yang menjadi kesepakatan bagi semua pihak. Nilainilai toleransi tersebut adalah:

a. Toleransi antar penganut suatu agama tertentu

b. Toleransi antar penganut agama yang berbeda

c. Toleransi antara penganut agama dengan pemerintah (Masykuri Abdillah,2000)

Dalam prinsip-prinsip universal toleransi antara umat beragama mengatakan bahwa prinsip-prinsip dalam toleransi agama ini, yang merupakan bagian dari visi ideologi atau juga akidah telah dimiliki oleh tiap-tiap agama maka sudah selayaknya jika setiap umat bergama turut untuk serta aktif untuk memperjuangkan visi-visi toleransinya di khalayak masyarakat plural. Perbedaan yang dimiliki oleh manusia berupa warna kulit, ras, suku, agama merupakan ketetapan Allah Sunnatullah, sehingga hal ini tidak bisa diubah namun umat manusia harus menjadikan ini sebagai pelajaran untuk saling menghargai satu sama lain. 


\section{Implementasi Pembelajaran Agama Islam Dalam Konteks Keberagaman Agama Peserta Didik di SMPN 13 Kota Kupang}

Berdasarkan hasil penelitian yang penulis lakukan dengan melakukan observasi dan wawancara kepada beberapa narasumber, penulis mendapatkan pernyataan mengenai implementasi pemebalajaran agama Islam yang diberikan kepada para peserta didik di SMPN 13 Kota Kupang, jika dilihat dari sudut pandang keberagaman agama yang ada di SMPN 13 maka agama Islam adalah agama minoritas dan agama Kristen Protestan dan agama Katolik menjadi agama mayoritas, namun tentu itu bukan menjadi halangan untuk para peserta didik yang beragama Islam untuk mempelajari agama Islam, karena pelajaran setiap agama sudah menjadi pelajaran yang diwajibkan kepada setiap jenjang dan jenis pendidikan yang ada di Indonesia, sesuai dengan ketetapan Peraturan Pemerintah Republik Indonesia No 55 tahun 2007 pasal 3 \& 4 tentang Pendidikan Agama dan Pendidikan Keagamaan yang berbunyi "Setiap satuan pendidikan pada semua jalur, jenjang, dan jenis pendidikan wajib menyelenggarakan pendidikan agama" dan "Pendidikan agama dan pendidikan formal dan program pendidikan kesetaraan sekurang-kurangnya diselanggarakan dalam bentuk mata pelajaran atau mata kuliah agama". (Peraturan Pemerintah Republik Indonesia Nomor 55 Tahun 2007)

Dalam kegiatan wawancara penulis yang terkait mengenai implementasi pembelajaran agama Islam yang diberikan kepada peserta didik jika dilihat dari sudut pandang keberagaman agama di SMPN 13 Kota Kupang, hasil wawancara dengan bapa Deddy Sanjaya sebagai berikut :

"Implementasi pelajaran agama Islam disini sebenarnya sama saja dengan sokolah-sekolah lain ya semuanya sama materinya tentang iman, wudu, solat, zakat, puasa dan lain-lainnya, kita ajarkan wudu itu tata caranya bagaimana, rukun2nya bagaimana begitu juga dengan materi lainnya. Buku yang kita pakai disini sama dengan buku di sekolah-sekolah lain buku yang didapat dari Dinas Pendiidkan kota Kupang yang kami gunakan, materi yang disampaikan juga sudah tertera dalam buku dan ditetapkan dari kurikulumkan. Disini kami pakainya kurikulum yang K13” (Deddy Sanjaya, 2020) 
Narasumber menjelaskan bahwasanya, implementasi pembelajaran agama Islam yang diberikan kepada peserta didik di SMPN 13 Kota Kupang pada dasarnya sama dengan sekolah-sekolah lainnya materi yang digunakan juga sama seperti sekolah-sekolah lainnya, beliau mengajar sesuai dengan materi yang ada di dalam buku dan yang ditetapkan dalam kurikulum. Buku paket yang digunakan pada kelas pelajaran agama Islam ialah "Pendidikan Agama Islam dan Budi Pekerti" baik untuk kelas VII, VIII, dan IX, buku paket ini adalah buku yang diterbitkan oleh Kementerian Pendidikan dan Kebudayaan. Materi yang ada di dalam buku paket ini tentu sama dengan sekolah-sekolah lain yang ada di kota Kupang, karena seluruh SMP Negeri yang ada di kota Kupang menggunakan buku yang sama yang didapat dari Dinas Pendidikan setempat, di dalam buku tersebut tentunya mengajarkan tentang materi-materi agama Islam pada umunya seperti iman, solat, zakat, puasa, dan lain-lainnya.

Bapak Deddy Sanjaya sendiri juga mengatakan bahwa, selama dia mengajar di SMPN 13 Kota Kupang dia tidak pernah menemukan faktor penghambat dari luar dalam implementasi pembelajaran agama Islam

“Kalau faktor penghambat itu tidak pernah ada kalau dari luar selama saya mengajar saya sama sekali tidak pernah menemukan itu, adanya kalau didalam kelas yaitu pada murid saya sendiri ya kita tau sendiri ini sekolah negeri dan anak-anaknya bermacam-macam ada yang cepat menangkap ada yang susah ada yang harus kita ajar pelan-pelan, yang paling susah itu ya soal mengaji dari setiap kelas itu paling hanya ada satu atau dua orang yang mengajinya lebih baik dari yang lain itupun masih pas di standarnya nah yang lain kakak tau sendirilah mereka bagaimana. Kalau mengenai interaksi sosial mungkin masalahnya tu pas lagi makan-makan kita kan tau dalam agama kita makan itu tidak bisa sembarang harus ada banyak hal yang kita pertimbangkan mengenai baik atau buruknya, sebenarnya itu saja ya mengenai makan itu yang membuat kita kurang nyaman tapi syukurnya teman-teman disini sudah paham itu dan kalau setiap ada makanmakan sudah mereka siapkan untuk kita sendiri kalau memang ada yang makan babi atau anjing, tapi kalau tidak ya kita sama-sama” (Deddy Sanjaya, 2020) 
Dalam pelaksanaan belajar mengajar khususnya, bapak Deddy Sanjaya tidak pernah sama sekali mendapatkan hambatan dari luar, tetapi justru hambatan yang ia temukan dari dalam kelasnya sendiri dimana ada peserta didik yang mungkin susah untuk memahami materi pelajaran dan juga beliau mengatakan bahwa, ketika mengaji memang tidak banyak yang bisa, ini merupakan suatu hal yang biasa yang pernah juga penulis temui ketika melaksanakan kegiatan PPL dimana ada anak yang susah menangkap materi dan susah dalam mengaji, ini merupakan tanggung jawab seorang guru sebagaimana yang dikatan oleh Samsul Nizar bahwasanya mendidik merupakan rangkaian mengajar, memberi dorongan, memuji, menghukum, memberi contoh, membiasakan. Jadi, tugas pendidik bukan hanya sekedar mengajar, diasmping itu guru brtugas sebagai motivator dan fasilitator dalamproses pembelajaran, sehingga seluruh potensi peserta didik dapat teraktualisasi secara baik dan dinamis. (Samsul Nizar, 2002:72)

Dari semua hasil wawancara diatas mengartikan bahwa guru telah memberikan suatu pembelajaran yang baik dan berguna, bukan hanya soal mengenai materi yang diberikan tetapi juga ada nilai-nilai sosial yang dipesankan pada setiap pertemuan. Melihat sesuatu secara pandangan Islam memang merupakan kewajiban tetapi tentu kita juga perlu melihat sesuatu secara pandangan sosial, karena sejatinya kita manusia merupakan makhluk sosial kita tidak bisa hidup sendiri dan saling ketergantungan satu sama lain itulah hakikat dari seorang manusia, maka dari itu dengan memiliki sikap toleransi dan nilai sosial yang baik akan membantu kita dalam hidup saling betergantungan. 


\section{Bentuk Peran Guru Pendidikan Agama Islam SMPN 13 Kota Kupang di Dalam Kelas dan di Luar Kelas}

Pada pembahasan kali ini penulis akan memaparkan hasil penelitian yang penulis dapatkan melalui wawancara dengan guru PAI di SMPN 13 Kota Kupang bapak Deddy Sanjaya, berikut adalah hasil wawancaranya:

"Syarat seseorang untuk bisa menjadi guru PAI itu yang pertama dia harus lulusan dari PAI atau sudah menjadi serjana PAI itu sudah pasti walaupun yang lainnya hanya sekedar membantu tapi syarat utamanya itu dulu serjana Pendidikan Agama Islam, terus yang kedua harus punya basic ilmu agama Islam sudah jelas memahami tentang agama Islam itu sendiri tapi kalau yang diluar serjana Pendidikan Agama Islam cuman hanya mengisi dalam artian seperti apa yang kita pelajari sejak mulai dari kecil sampai pada saat sekarang ya hanya ituitu saja kan secara spesifik ya tentang mengaji, solat, zakat, puasa, dan lainnya." (Deddy Sanjaya, 2020)

Berdasarkan hasil wawancara diatas, syarat menjadi seorang guru PAI menurut bapak Deddy Sanjaya sebagai narasumber pertama yaitu:

1. Memiliki serjana Pendidikan Agama Islam atau lulusan Pendidikan Agama Islam

2. Memiliki basic tentang ilmu agama Islam

3. Sehat rohani dan jasmani

4. Memiliki niat dalam mengajar dan bertanggung jawab atas apa yang diajarkan

5. Memiliki akhlak yang baik

Dari 5 syarat diatas dapat kita ketahui bahwasanya untuk dapat menjadi seorang guru PAI tidaklah mudah, ada syarat-syarat yang harus dimiliki oleh seorang calon guru PAI karena, mengajarkan tentang ilmu agama Islam bukan seperti pelajaran-pelajaran biasa yang hanya dapat diterapkan selama kita hidup di dunia, tetapi dalam ilmu agama Islam ada amalan-amalan yang dilakukan selama hidup di dunia yang akan dipertanggung jawabkan di akhirat kelak nanti, dengan begini seorang guru PAI memiliki tanggung jawab double yaitu tanggung jawab 
di dunia dan juga tanggung jawab di akhirat kelak. Hal ini diperkuat dengan teori yang penulis gunakan yaitu menurut Zakiah Daradjat, seseorang dipandang mampu menjadi guru agama Islam apabila memiliki syarat sebagai berikut:

1. Bertaqwa kepada Allah SWT

2. Berilmu

3. Sehat jasmani

4. Berakhlak baik (Zakiah Darajat, 2006:41-42)

Jika melihat dari sudut pandang agama Islam sebagai minoritas pembelajaran dalam kelas tetaplah sama, menyampaikan materi-materi sesuai dengan ketetapan kurikulum, hanya saja ada tambahan yang diberikan oleh guru didalam kelas yaitu berupa nilai-nilai sosial dan toleransi seperti yang telah penulis bahas sebelumnya.

“Kalau luar kelasnya paling kita kalau ada kegiatan-kegiatan keagamaan seperti umpama di agama yang lain ya kami arahkan kita tidak perlu ikut karena apa ini masalah aqidah kita hanya sekedar menyaksikan dan menghargainya itu diluar dari kelas, kalau kami ada kegiatan doa bersama ya kami masing-masing berdoa, tetap berada dalam satu ruangan tapi cara berdoanya masing-masing. Kalau untuk di masyarakat sendiri peran saya sebagai guru agama ya biasanya diminta untuk mengisi khutbah jumat di beberapa masjid, atau ketika ada tahlilan saya diminta untuk memimpin tahlilannya, kadang juga tetangga yang non muslim misalnya mereka lagi ada pesta (kondangan) atau acara nikahan yang ada sapi atau kambing mereka minta saya yang potong karena mereka sudah percaya dan juga kalau sudah dipotong itu mereka kasih daging mentah biar saya yang masak sendiri di rumah haha... mungkin kalau di jawa atau ditempat lain keliatan aneh tapi itu merupakan salah satu bentuk dari nilai toleransi yang ada di masyarakat kita." (Deddy Sanjaya, 2020)

Melalui hasil wawancara yang didapatkan dan dengan hasil tinjauan terhadap masyarakat sekitar, peran seorang guru PAI di masyarakat sangat penting karena, tugas guru PAI bukan hanyalah sekedar saat berada di sekolah tetapi ketika berada di masyarakat pun guru PAI memiliki pengaruh untuk umat Islam 
maupun yang non Islam. Saling membantu sama lain tanpa harus memandang agama atau golongan itulah hal yang paling utama, karena didalam Islam sendiripun kita diminta untuk saling tolong menolong dan saling mengasihi antara umat manusia. Islam memerintahkan kita untuk menjaga keseimbangan antara Hablumminallah dan Hablumminannas, setiap ibadah yang Allah perintahkan bertujuan untuk meningkatkan hubungan vertikal dan horizontal agar seimbang. Hubungan vertikal yaitu hubungan ubudiyah kita kepada Allah (Hablumminallah), sedangkan hubungan horizontal ialah hubungan muamalah kita kepada sesama makhluk Allah lainnya (Hablumminannas). Hablumminallah adalah konsep dimana kita sebagai manusia dengan sang pencipta Allah dengan mengikuti segala perintahnya dan menjauhi segala larangannya sedangkan Hablumminannas adalah konsep dimana individu manusia menjaga hubungan baik dengan individu lain atau kelompok manusia lainnya. Kedua hal ini sangat penting di mata Allah kita tidak bisa mementingkan hanya satu saja tetapi harus kedua-duanya kita lakukan bukan hanya kepada Allah saja tetapi juga kepada sesama manusia itu wajib kita laksanakan. Hal ini diperkuat dengan adanya pendapat menurut Tafsir Min Fathil Qadir dimana Allah tidak akan pernah melarang umatnya untuk berbuat baik kepada orang-orang yang tidak memeranginya dna Allah juga memerintahkan kita untuk saling bersilaturahmi ke sesama tetangga. (Imam Asy-Syaukani, 2012:477)

Peranan seorang guru dimasyarakat sangatlah penting karena tugas seorang guru bukan hanya ketika dia berada di lingkungan sekolah tetapi juga ketika di luar dari lingkungan sekolah. Dian Rahadian mengungkapkan bahwa guru memelihara hubungan dengan masyarakat disekitar sekolahnya maupun masyarakat secara luas untuk kepentingan pendidikan dan guru turut bersamasama masyarakat sekitarnya didalam berbagai aktifitas. (Dian Rahadian, 2012:26) Didalam lingkukan sekolah maupun lingkungan masyarakat guru merupakan tauladan yang patut dicontoh. Hal ini menuntut kemampuan guru untuk bersosial dengan masyarakat, dalam kemampuan sosial tersebut meliputi kemampuan guru dalam berkomunikasi, bergaul, dan mempunyai jiwa yang menyenangkan. Peranan guru di dalam masyarakat akan selalu dipandang dan dinilai oleh 
masyarakat tentang kualitas dia sebagai guru serta kompetensi dalam profesinya. Kualitas seorang guru juga ditentukan dari bagaimana peran dia di masyarakat.

Dengan demikian guru haruslah memiliki jiwa profesional yang tinggi selain mengajar di sekolah guru juga tentu hidup ditengah kelompok masyarakat yang beragam, guru dituntut untuk bisa menjadi tauladan di lingkungan sekolah dan juga lingkungan masyarakat, kemampuan dalam mengajar disekolah belumlah cukup untuk menjadikan seorang guru sebagai seorang yang patut untuk dicontoh kemampuan dalam berinteraksi dan merangkul di tengah masyarakat juga dinilai sangat penting, jika seorang guru sudah memiliki kedua kemampuan tersebut barulah guru tersebut dapat dikatakan sebagai guru yang profesional.

\section{KESIMPULAN}

Dari penelitian diatas penulis dapat mengambil kesimpulan sebagai berikut:

1. Upaya yang dilakukan oleh guru Pendidikan Agama Islam dan juga pihak sekolah dalam membangun semangat keberagaman beragama yang ada di SMPN 13 Kota Kupang dilakukan dengan cara-cara seperti mengajarkan mengenai nilai-nilai sosial dan keberagaman di dalam kelas, pihak sekolah membangun semangat keberagaman beragama dengan visi semangat berintegrasi dan juga misi menumbuh kembangkan semangat toleransi dan cinta tanah air.

2. Dalam implementasi pembelajaran agama Islam yang diberikan kepada peserta didik menggunakan buku ajar yang diterbitkan oleh kemendikbud, materi yang diajarkan sesuai dengan apa yang ditetapkan oleh kurikulum. Selama proses implementasi pembelajaran guru tidak pernah mendapatkan hambatan secara internal setiap elemen yang ada di SMPN 13 Kota Kupang saling mendukung dan mensupport satu sama lain.

3. Peran guru Pendidikan Agama Islam di dalam kelas selain mengajarkan materi-materi yang sesuai dengan kurikulum, guru juga mengajak dan memberikan contoh yang baik. Guru juga memiliki peran diluar kelas berupa saling membantu sama lain, bergotong royong, dan juga silaturahmi dan berbagi ke sesama tetangga yang harus terus dijaga. 


\section{DAFTAR PUSTAKA}

Abdillah, Masykuri. 2000. Toleransi Beragama dalam Masyarakat Demokrasi dan Multikultural. Opini Kompas. Edisi 31 Maret.

Ahmad, Muhammad Abdul Qadir. 2008. Metodologi Pengajaran Agama Islam, Jakarta: Rineka Cipta.

Ali, Mohammad. 2013. Penelitian Pendidikan; Prosedur dan Strategi. Bandung: Angkasa.

Al-Maraghi, Ahmad Al-Mustafa. 1993. Terjemahan Tafsir Al-Maraghi, Juz IV, terj. Bahrun Abu Bakar. Semarang: Toha Putra.

Arifin, H. M. 1991. Ilmu Pendidikan Islam. Jakarta: Bumi Aksara.

Arifin, Muzayyin. 2003. Kapita Selekta Pendidikan Islam. Jakarta: Bumi Aksara.

Catarats. 2009. Manusia, Keragaman, dan Kesetaraan. Edisi Maret.

Djamarah, Syaiful Bahri dan Aswan Zain. 2014. Strategi Belajar Mengajar Jakarta: PT Rineka Cipta.

Djamarah, Syaiful Bahri. 2000. Guru dan Anaka Didik Dalam Interaksi Edukatif. Jakarta: Rineka Cipta.

Darajat, Zakiah. 2006. Ilmu Pendidikan Islam. Jakarta: Bumi Aksara.

Dapartemen Agama RI. 1996. Al-Qur'an dan Terjemahannya. Semarang: Toha Putra.

Faisal, Sanapiah. 1990. Penelitian Kualitatif (Dasar-Dasar dan Aplikasi). Malang: Ya3.

Hailil. 2018. Indeks Kota Toleran 2018. Pustaka Masyarakat Setara, November 2018.

Imam As-Syaukani. 2012. Tafsir Fathul Qadir. Jakarta: Pustaka Azzam

Kartini, Revinna Ornela. 2019. Toleransi Dalam Keberagaman di Sekolah Mayoritas Budha. Padang: FIS Universitas Negeri Padang. Volume 2, Nomor 1.

Marimba, Ahmad D. 1998. Filsafat Pendidikan Islam. Jakarta: Bulan Bintang. 
Masamah, Ulfa dan Muhammad Zamahari. 2016. Peran Guru Dalam Membangun Pendidikan Berkesadaran Multikultural di Indonesia. Yogyakarta: UIN Sunan Kalijaga. Volume 4, Nomor 2.

Miftahudin Khairi. 2016. Peran Guru PAI Dalam Menanamkan Sikap Toleransi Beragama Pada Siswa-Siswi di SMPN 14 Mataram Tahun Pelajaran. 2015/2016. Mataram: IAIN Mataram.

Muhadi. 2014. Interaksi Sosial Dalam Keberagaman Umat Muslim Masyarakat Giri Asih, Gunung Kidul, Yogyakarta. Yogyakarta: Kontekstualita. Volume 29, Nomor 2.

Muhammad Ihwan Harahap. 2017. Peran Guru PAI Dalam Menerapkan Pendidikan Multikultural di SMK Karya Bunda Medan Estate. Medan UIN Sumatera Utara.

Muhammad bin Islamin bin Ibrahim. 1981. Shahih Al-Bukhari. Beirut: Darul Al Fikr.

Nizar, Samsul. 2002. Filsafat Pendidikan Islam, Pendekatan Teoritis dan Praktis. Jakarta: Ciputat Press.

Nursyamsi, 2003. Psikologi Pendidikan. Padang: Baitul Hikmah Press. Peraturan Pemerintah Republik Indonesia Nomor 55 Tahun 2007. Pendidikan Agama dan Pendidikan Keagamaan. Jakarta: Kementerian Agama Republik Indonesia.

Poppy Nurhayati. 2017. Peran Guru Pendidikan Agama Islam Dalam Pengembangan Sikap Inklusif di SMAN 1 Wonogiri Tahun Pelajaran 2017/2018. Surakarta: IAIN Surakarta.

Purwanto, Ngalim. 1994. Ilmu Pendidikan Teoritis dan Praktis. Bandung: Remaja Rosda Karya.

Qarni, Aidh bin Abdillah. 2007. Tafsir Muyassar Jilid Ke empat. Jakarta: Qisti press.

Rahadian, Dian. Peran dan Kedudukan Guru Dalam Masyarakat. Jurnal Pendidikan Teknologi dan Informasi.

Ramayulis. 2004. Pengantar Ilmu Pendidikan. Padang: The Minangkabau Foundation Press. 
Shihab, M. Quraish. 2006. Tafsir Al-Misbah, Pesan, Kesan dan Keserasian Al Qur'an. Jakarta: Lantera Illahi.

Soekantono, Soerjono. 2006. Sosiologi Suatu Pengantar. Jakarta: Raja Grapindo Persada.

Sudirman, A. M. 1990. Interaksi dan Motivasi Belajar Mengajar. Jakarta: Raja Grafindo.

Syafrilsyah dan Maulina. 2015. Sikap Toleransi Beragama di Kalangan Siswa SMA di Banda Aceh. Banda Aceh: Jurnal Substansia. Volume 17, Nomor 1.

Syuhudi, Irfan. 2017. Mengelola Keberagaman Agama di Sekolah Manado (Studi Kasus: SMK Kristen YPKM dan SMA Thridharma. Jurnal Al-Qalam. Volume 23, Nomor 2.

Tafsir, Ahmad. 2000. Ilmu Pendidikan Dalam Perspektif Islam. Bandung: Remaja Rosda Karya.

Ubhiyati, Nur. 1998. Ilmu Pendidikan Islam. Bandung: Pustaka Setia.

Yuyun Prafita Anwar. 2018. Peran Guru Pendidikan Agama Islam Dalam Menerapkan Pendidikan Multikultural di SMAN 1 Gunung Sugih Lampung Tengah. Lampung: UIN Raden Intan Lampung. 